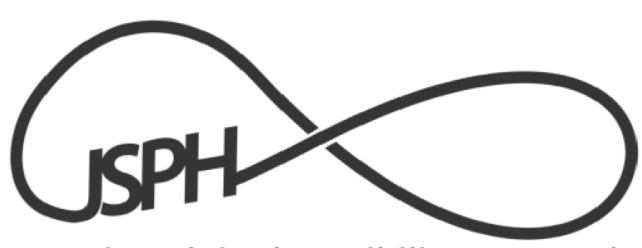

Jurnal Sosiologi Pendidikan Humanis
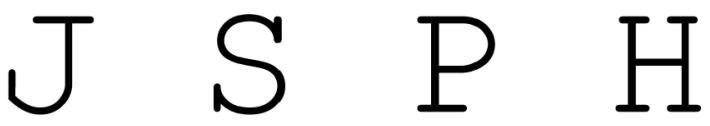

Jurnal Sosiologi Pendidikan Humanis

Volume 1, Nomor 2, Desember 2016, Halaman 173 - 182

E-ISSN 2527-5879 P-ISSN 2527-5879

http://journal.um.ac.id/index.php/jsph

\title{
MANIFESTASI PENDIDIKAN KRITIS (PENDIDIKAN HADAP MASALAH SEKOLAHALTERNATIF QARYAH THAYYIBAH DI SALATIGA)
}

\section{Nora T. Ayudha}

Peneliti dan Pendamping Lapangan Wahana Visi Indonesia (WVI)

Email: ayudhanora@gmail.com

\begin{abstract}
Abstrak
Studi ini dilakukan untuk menjelaskan argumentasi sekolah alternatif Qaryah Thayyibah yang menolak menggunakan pendidikan yang telah mapan dan menjadi arus utama. Serta bagaimana metode manifestasi pendidikan kritis yang diterapkan di sekolah tersebut. Metode yang digunakan dalam penelitian ini adalah metode kualitatif, dengan tipe penelitian deskriptif. Teknik penentuan informan yang digunakan adalah dengan teknik purposive, dan jumlah informan dalam penelitian ini berjumlah tujuh informan. Penelitian ini menggunakan teori pendidikan hadap-masalah sebagai analisa untuk menjelaskan permasalahan penelitian. Berdasar pemikiran sekolah Qaryah Thayyibah, pendidikan yang selama ini dijalankan nyatanya melanggengkan sistem penindasan, dengan guru sebagai pihak yang mendominasi terhadap muridnya. Dalam mode pendidikan ini, ijazah dijadikan legitimasi hasil belajar dengan anggapan sebagai tafsiran kemampuan seseorang. Maka bertolak dari fakta tersebut, Qaryah Thayyibah menggunakan pendekatan berbeda dalam aktivitas pembelajarannya. Murid mempunyai otoritas penuh dalam menciptakan sistem pendidikan dan guru sebatas pendamping adalah prinsip dari pembelajaran ini. Selain itu, karya menjadi alternatif tolak ukur yang lebih adil dalam menilai sebuah kemampuan.
\end{abstract}

Kata kunci : Qaryah Thayyibah, sistem pendidikan, pendidikan hadap masalah

\section{MANIFESTATION OF CRITICAL EDUCATION (FACING EDUCATION PROBLEM ON ALTERNATIVE SCHOOL QARYAH THAYYIBAH IN SALATIGA)}

\begin{abstract}
This study was conducted to elucidate arguments Qaryah Thayyibah alternative school that refuses to use the education that has been established and become mainstream. And how the manifestation of critical education methods applied at the school. The method used in this research is qualitative method with descriptive research type. Informant determining technique used is purposive, and the number of informants in this study were seven informants.

This study uses the theory of education facing problems as the analysis to explain the research problems. Based Thayyibah Qaryah school of thought, education during this run in fact perpetuate systems of oppression, with the teacher as the party that dominates on his student. In this mode of education, diploma made with the presumption of legitimacy of learning outcomes as a person's interpretation capabilities. Then departed from the facts, Qaryah Thayyibah use a different approach in learning activities. Pupils have full authority in creating a system of teacher education and the extent of the companion is principle of this learning. In addition, the work becomes an alternative fairer yardstick in judging a capability.
\end{abstract}

Kata kunci : Qaryah Thayyibah, sistem pendidikan, pendidikan hadap masalah 


\section{PENDAHULUAN}

Pendidikan di Indonesia dari tahun ke tahun tidak ada niatan serius untuk berbenah dan menanggulangin permasalahan-permasalahannya. Headline media massa selalu mendokumentasikan prahara ketimbang gemilang prestasi. Sebut saja dari yang mikro yaitu kekerasan atau bullying di sekolah, fasilitas bangunan sekolah rusak, hingga yang makro seperti disparitas pendidikan, tidak meratanya kuantitas dan kualitas guru, dan lain-lain. Ada dua tema besar yang akan dikemukakan pada penelitian ini, yaitu komersialisasi pendidikan dan permasalahan sistem pendidikan di Indonesia.

Dalam Undang-Undang Dasar negara Indonesia di sebutkan bahwa setiap warga negara berhak mendapatkan pendidikan, hal ini dapat dimengerti secara sederhana bahwa negara menjamin akses pendidikan warga negaranya. Namun, kenyataannya pendidikan menjadi komoditas yang semakin hari semakin susah diakses, khususnya golongan masyarakat ekonomi menengahke bawah. Adalah WTO dan IMF menjadi dalang yang mendorong pendidikan menjadi komoditas yang dapat diperjualbelikan.

WTO memasukkan bidang pendidikan ke dalam bidang tersier (Efendi, 2007), dengan argumentasi bahwa pendidikan termasuk ke dalam kategori industri yang mengubah benda fisik (physical services), keadaan manusia (human service) dan benda simbolik (information and communication services), di mana kegiatan pokoknya adalah mentransformasi orang yang tidak berpengatahuan dan tidak memiliki keterampilan menjadi memiliki pengetahuan dan keterampilan.
Prinsip dan peraturan dari WTO adalah adanya jaminan atas perdagangan bebas, sehingga semua bentuk kebijakan dan tindakan yang menghalangi atau mengurangi persaingan bebas harus dihilangkan. Indonesia termasuk salah satu negara yang menandatangani pembentukan WTO dan GATS, konsekuensinya Indonesia harus tunduk pada ketentuan-ketentuan WTO/GATS ini dalam meliberalisasi, salah satunya sektor pendidikan. Ratifikasi WTO ditandai dengan disahkannya Undang-Undang no. 7 tahun 1994 tentang pengesahan Agreement Established The World Trade Organization (Persetujuan Pembentukan Organisasi Perdagangan Dunia). Selang 11 tahun kemudian ditandatangani penandatangan lanjutan GATS di tahun 2005. Setelah peritiwa itu, pemerintah kemudian mengeluarkan Perautan Presiden (Perpres) No. 76 tahun 2007 dan Perpres tahun 77 tahun 2007 yang menyatakan bahwa pendidikan termasuk sektor yang terbuka bagi penanaman modal asing, maksimal sampai 49 persen (Dharmaningtyas, Subhan \& Panimbang: 2009).

Dengan nalar seperti ini, maka jelas bahwa subyek peserta didik sebagai modal manusia (human capital), dan kemudian upaya negara dalam bertanggung jawab terhadap warga negara akan kebutuhan pendidikan terus digerus, diperkecil bahkan dihilangkan, sedangkan peranan korporasi melalui modal asing diupayakan dominan. Kenyataan ini tak ubahnya merupakan korporatisasi pendidikan, atau swastanisasi institusi-institusi pendidikan. ${ }^{1}$ Hal ini menyebabkan pergeseran paradigma pendidikan menjadi ke arah komersialisasi yang kapitalistik. Pendidikan dan ilmu pengetahuan dianggap sebagai ko-

${ }^{1}$ Korporatokrasi pendidikan adalah istilah untuk menunjukkan penerapan budaya perusahaan di dalam dunia pendidikan, yang berarti juga merupakan komersialisasi pendidikan 
pengetahuan dianggap sebagai komoditas yang bebas diperjualbelikan. Inilah logika komersialisme pendidikan yang lebih berat pada logika ekonomi kapitalis, bukan lagi berparadigma intelektualisme, kebudayaan dan humanisme.

Sistem Pendidikan di Indonesia diatur melalui Undang-Undang nomor 20 tahun 2003. Mandat diemban oleh Kemdikbud (Kementrian Pendidikan dan Kebudayaan). ${ }^{2}$ Berbicara tentang sistem pendidikan, kita tidak bisa lepas dengan kurikulum, kurikulum dirumuskan sebagai penunjuk arah bagaimana visi dan misi pendidikan diemban. Saat ini kurikulum yang digunakan adalah kurikulum 2013. Tujuan kurikulum 2013 adalah ingin mewujudkan pola belajar-mengajar yang membuat siswa aktif bertanya dan guru dilarang berceramah terlebih dahulu (Ratri, 2013).

Menurut Rosalia Wiwiek Wahyuning Ratri, salah seorang guru SMP dalam tulisannya mengungkapkan realitas yang dihadapi ketika ia mengajar adalah ruang kelas menjadi sunyi, tidak ada aktifitas siswa bertanya banyak hal kepada guru dan akhirnya guru harus menggunakan model yang konvensional, banyak ceramah, menyebarkan lembar kerja siswa, atau kegiatan lain. menurutnya, ada lima hal mengapa siswa tidak aktif bertanya.

Problematika atas hadirnya kurikulum ini tidak saja dirasakan olehnya saja, namun gelombang protes dilayangkan oleh Forum Serikat Guru Indonesia (FSGI). Menurut Sekjen FSGI, penerapan kurikulum 2013 telah menimbulkan beberapa masalah, antara lain : dimulai dari kekacauan distribusi buku, pelatihan guru yang tidak efektif, dan sistem peni- laian yang membingungkan (Jayabuana: 2015).

Dari sisi pelaksanaan, kurikulum 2013 juga menuai kontroversi. Menurut Febby Hendri, Badan pekerja Indonesia Corruption Watch (ICW), pemberlakuan kurikulum 2013 secara tiba-tiba ini memicu spekulasi adanya intervensi politik atas kurikulum ini (Hendri, 2014). Ia mendapati dalam pantauannya, kurikulum 2013 disinyalir sarat kepentingan pihak yang ingin dapat keuntungan dari penjualan buku. Bagi birokrasi, perubahan kurikulum merupakan proyek baru dan tentu anggaran yang sangat besar. Kurikulum baru, misalnya, mensyaratkan pelatihan bagi guru yang jumlahnya dua juta lebih di seluruh Indonesia.

Berbagai permasalahan yang melanda dunia pendidikan mendorong Ahmad Bahruddin mendirikan sekolah yang bernama Sekolah Alternatif Qaryah Thayyibah yang terletak di desa kalibening kota Salatiga. Beberapa alasan yang mendasari adalah permasalahan biaya dan kualitas pendidikan itu sendiri. Qaryah Thayyibah hadir dengan agenda menjadi alternatif bagi sistem pendidikan yang telah mapan, yaitu sistem pendidikan formal. Salah satu yang ditawarkan adalah Pendidikan berbasis komunitas, pendidikan berbasis komunitas itu sendiri merupakan mekanisme yang memberikan peluang bagi setiap orang untuk memperkaya ilmu pengetahuan dan teknologi melalui pembelajaran seumur hidup. Pendidikan ini memberikan tempat seluasluasnya bagi partisipasi masyarakat (Sudjana, 2000). Dengan inovasi di dunia pendidikan ini, SMP AlternatifQaryah Thayyibah di

${ }^{2}$ Setelah berganti rezim, saat ini pemerintahan periode 2014-2019 membuat sebuah terobosan dengan membagi dua kementerian yang mengurusi bidang pendidikan, yaitu Menteri Kebudayaan dan Pendidikan Tinggi dan Menteri Ristek dan Perguruan Tinggi 
Kalibening Salatiga Jawa Tengah sejajar dengan Tujuh Intellegent Communities sebagai keajaiban dunia yang terpilih sebagai pengguna ICT terbaik di dunia tahun 2005. Kampung Issy-Les Moulienauk di Perancis, Kecamatan Mitaka di Tokyo, Kecamatan Pirai di Brazil, sebuah kampung di Singapura, Kampung Sunderland di Inggris, Kota Tianjin di China, dan Kota Toronto di Kanada (Baharuddin 2007:229).

\section{KAJIAN TEORITIK}

Teori yang digunakan dalam penelitian ini adalah teori dari Paulo Freire, yang membahas mengenai pendidikan gaya bank dan pendidikan hadap masalah (Freire 2007; Hidayat 2013; Fakih, Rahardjo \& Topatimasang, 2010). Studi ini dikotomi dua pendidikan Freire dengan maksud ingin melihat bagaimana Qaryah Thayyibah melihat sistem pendidikan saat ini dan tawaran yang diberikan Qaryah Thayyibah dari hasil ketidakpuasannya dengan kondisi pendidikan saat ini. Secara filosofis, pemikiran Freire banyak dipengaruhi oleh aliran pemikiran Fenomenologi, personalisme, eksistensialisme, dan Marxisme (Pazmino, 1988:68). Sebagai tokoh pendidikan pendidikan, ia dikenal sebagai salah satu tokoh utama Rekonstruksionisme (Ozmon \& Craver, 1986: 163).

\section{Pendidikan Kritis Paulo Freire Pendidikan}

\section{Gaya Bank}

Pemikiran Paulo Freire tentang pendidikan lahir dari pergumulannya selama bekerja bertahun-tahun di tengah-tengah masyarakat desa yang miskin dan tidak “berpendidikan” (Schipani, 1988:12). Dalam sistem pendidikan yang diterapkan di Brasilia pada masa Freire, anak didik tidak dilihat sebagai yang dinamis dan punya kreasi tetapi dilihat sebagai benda yang seperti wadah untuk menampung sejumlah rumusan/dalil pengetahuan. Semakin banyak isi yang dimasukkan oleh gurunya dalam "wadah" itu, maka semakin baiklah gurunya. Karena itu semakin patuh wadah itu semakin baiklah ia. Jadi, murid/peserta didik hanya menghafal seluruh yang diceritakan oleh gurunya tanpa mengerti (Schipani, 1988:50).

Peserta didik adalah obyek dan bukan subyek. Pendidikan yang demikian itulah yang disebut oleh Freire sebagai pendidikan "gaya bank". Disebut pendidikan gaya bank sebab dalam proses belajar mengajar guru tidak memberikan pengertian kepada peserta didik, tetapi memindahkan sejumlah dalil atau rumusan kepada siswa untuk disimpan yang kemudian akan dikeluarkan dalam bentuk yang sama jika diperlukan. Peserta didik adalah pengumpul dan penyimpan sejumlah pengetahuan, tetapi pada akhirnya peserta didik itu sendiri yang "disimpan" sebab miskinnya daya cipta.

Karena itu pendidikan gaya bank menguntungkan kaum penindas dalam melestarikan penindasan terhadap sesamanya manusia. Pendidikan gaya bank memelihara bahkan mempertajam kontradiksi itu melalui cara-cara dan kebiasaan-kebiasaan sebagai berikut, yang mencerminkan suatu keadaan masyarakat tertindas secara keseluruhan (Freire, 1985: 65).

Pada pendidikan 'gaya bank', pengajar/pendidik merupakan sebuah subjek aktif sedangkan para peserta didik merupakan objek yang pasif, yang diperlakukan sama halnya objek realitas dunia yang diajarkan kepada mereka. Sehingga yang terjadi ialah pendidikan tidak memiliki fungsi yang searah 
dimana pengajar hanya memberi informasi searah yang ditelah secara mentah oleh para peserta didik, yang kemudian para peserta didik wajib untuk mengingat dan menghafal (Kodir, 2015:2).

Pendidikan "gaya bank" itu ditolak dengan tegas oleh Paulo Freire. Penolakannya itu lahir dari pemahamannya tentang manusia. Ia menolak pandangan yang melihat manusia sebagai mahluk pasif yang tidak perlu membuat pilihan-pilihan atas tanggung jawab pribadi mengenai pendidikannya sendiri (Subagi, 1985). Bagi Freire manusia adalah makhluk yang berelasi dengan Tuhan, sesama dan alam. Dalam relasi dengan alam, manusia tidak hanya berada di dunia tetapi juga bersama dengan dunia (Freire, 1970, 51).

Kesadaran akan kebersamaan dengan dunia menyebabkan manusia berhubungan secara kritis dengan dunia. Manusia tidak hanya bereaksi secara refleks seperti binatang, tetapi memilih, menguji, mengkaji dan mengujinya lagi sebelum melakukan tindakan. Tuhan memberikan kemampuan bagi manusia untuk memilih secara reflektif dan bebas. Dalam relasi seperti itu, manusia berkembang menjadi suatu pribadi yang lahir dari dirinya sendiri. Bertolak dari pemahaman yang demikian itu, maka ia menawarkan sistem pendidikan alternatif sebagai pengganti pendidikan "gaya bank" yang ditolaknya. Sistem pendidikan alternatif yang ditawarkan Freire disebut pendidikan 'hadapmasalah'.

\section{Pendidikan "Hadap-Masalah": Suatu Pen- didikan Alternatif.}

Pendidikan "hadap-masalah" sebagai pendidikan alternatif yang ditawarkan oleh Freire lahir dari konsepsinya tentang manusia.
Manusia sendirilah yang dijadikan sebagai titik tolak dalam pendidikan hadap-masalah. Manusia tidak mengada secara terpisah dari dunia dan realitasnya, tetapi ia berada dalam dunia dan bersama-sama dengan realitas dunia. Realitas itulah yang harus diperhadapkan pada peserta didik supaya ada kesadaran akan realitas itu.

Konsep pedagogis yang demikian didasarkan pada pemahaman bahwa manusia mempunyai potensi untuk berkreasi dalam realitas dan untuk membebaskan diri dari penindasan budaya, ekonomi dan politik (Schipani, 1998: 13). Kesadaran tumbuh dari pergumulan atas realitas yang dihadapi dan diharapkan akan menghasilkan suatu tingkah laku kritis dalam diri peserta didik.

Bagi Freire pendidikan yang membebaskan adalah pendidikan yang menumbuhkan kesadaran kritis transitif. Memang ia tidak bermaksud bahwa seseorang langsung mencapai tingkatan kesadaran tertinggi itu, tetapi belajar adalah proses bergerak dari kesadaran peserta didik pada masa kini ke tingkatan kesadaran yang di atasnya. Dalam proses belajar yang demikian kontradiksi guru-murid (perbedaan guru sebagai yang menjadi sumber segala pengetahuan dengan murid yang menjadi orang yang tidak tahu apa-apa) tidak ada. Peserta didik tidak dilihat dan ditempatkan sebagai obyek yang harus diajar dan menerima.

Demikian pula sebaliknya guru tidak berfungsi sebagai pengajar. Guru dan murid adalah sama-sama belajar dari masalah yang dihadapi. Guru dan peserta didik bersamasama sebagai subyek dalam memecahkan permasalahan. Guru bertindak dan berfungsi 
sebagai koordinator yang memperlancar percakapan dialogis. Ia adalah teman dalam memecahkan permasalahan. Sementara itu, peserta didik adalah partisipan aktif dalam dialog tersebut. Materi dalam proses pendidikan yang demikian tidak diambil dari sejumlah rumusan baku atau dalil dalam buku paket tetapi sejumlah permasalahan.

Permasalahan itulah yang menjadi topik dalam diskusi dialogis itu yang diangkat dari kenyataan hidup yang dialami oleh peserta didik dalam konteksnya sehari-hari, misalnya dalam pemberantasan buta huruf. Pertama-tama peserta didik dan guru secara bersama-sama menemukan dan menyerap tema-tema kunci yang menjadi situasi batas (permasalahan) peserta didik. Tema-tema kunci tersebut kemudian didiskusikan dengan memperhatikan berbagai kaitan dan dampaknya. Dengan proses demikian peserta didik mendalami situasinya dan mengucapkannya dalam bahasanya sendiri. Inilah yang disebut oleh Freire menamai dunia dengan bahasa sendiri. Kata-kata sebagai hasil penamaan sendiri itu kemudian dieja dan ditulis. Proses demikian semakin diperbanyak sehingga peserta didik dapat merangkai kata-kata dari hasil penamaannya sendiri.

\section{Dialog}

Pendidikan saat ini harus berangkat dari proses dialogis antar sesama subjek pendidikan. Dialog menjadi hal yang sangat penting dan berperan besar. Hanya dialog yang dapat menuntut pemikiran kritis dan melahirkan komunikasi. Tanpa adanya dialog tidak mungkin akan terjadi komunikasi dan pendidikan yang sejati. Sebagai respon tentang adanya praktek pendidikan anti realitas, Freire menegaskan bahwa pendidi- dikan harus diarahkan pada proses hadap masalah. Titik tolak penyusunan pendidikan atau politik harus beranjak dari hal konkret yang mencerminkan aspirasi rakyat. Program ini diharapkan dapat merangsang kesadaran rakyat dalam menghadapi tema-tema realitas kehidupan. Secara keseluruhan praktek pendidikan pedagogis dapat dirangkum dalam dua kata yaitu dialogis dan hadap masalah.

Menurut Freire, kesadaran kritis sangat lekat dengan peran dialog dalam proses pendidikan yang merupakan suatu hubungan yang horizontal antara pribadi yang satu dengan pribadi yang lain (Freire, 1985: 56). Di dalam suatu dialog kita akan menemukan banyak hal yang salah satunya adalah kata. Paulo menegaskan bahwa di dalam kata terdapat dua komponen yaitu refleksi dan tindakan. Dialog adalah bentuk perjumpaan diantara sesama manusia, dengan perantaan dunia, dalam rangka menamai dunia. Unsurunsur suatu dialog antara lain:

1. Rasa cinta yang mendalam terhadap dunia dan terhadap sesama manusia.

2. Kerendahan hati.

3. Menurut adanya kayakinan yang mendalam terhadap diri manusia.

4. Harapan.

\section{METODE PENELITIAN}

Proses penelitian ini menggunakan metode penelitian kualitatif, dimana penelitian kualitatif yang berusaha menekankan sifat realitas yang terbangun secara sosial, yang memiliki hubungan eratantara peneliti dengan subjek yang diteliti (Denzin \& Lincoln, 2009). Dalam penelitian ini, peneliti menggunakan penelitian deskriptif, (Moleong, 2007). Setiap penelitian deskriptif mencoba mencari deskripsi yang tepat dan cukup 
dari semua aktivitas, objek, proses, dan manusia. Lokasi penelitian dilakukan dimana sekolah Qaryah Thayyibah didirikan, yaitu desa Kalibening, Kecamatan Tingkir, kota Salatiga. Pemilihan informan dalam penelitian ini menggunakan teknik purposive sampling. Informan yang dilibatkan dalam penelitian ini adalah individu-individu yang menjadi stakeholder sekolah alternatif Qaryah Thayyibah, yaitu Pendiri, siswa, alumni, orang tua siswa, dan fasilitator. Jumlah informan dalam penelitian ini adalah tujuh orang. Studi ini menggunakan teknik pegumpulan data dengan menggunakan dua data, data primer (wawancara mendalam dan observasi) dan data sekunder (data pendukung seperti buku, buku, jurnal, dan lain-lain). Langkah berikutnya adalah mengorganisasikan atau mengolah data yang dilakukan dengan beberapa cara yaitu pertama, membuat pemetaan (mapping). Langkag kedua adalah penyajian data, penyajian data lebih terfokus meliputi ringkasan terstruktur, dan sinopsis.

\section{PEMBAHASAN}

Bagi Freire, pendidikan gaya bank itu sendiri didasarkan pada cara pandang mekanis dari kesadaran, pendidikan banking memisahkan pelajar dari isi dan proses pendidikan. Metafor banking berasumsi bahwa ilmu pengetahuan adalah semacam barang, seperti uang yang bisa ditransfer dari satu orang kepada orang lain. pendidikan banking berarti ilmu pengetahuan ditransfer dari pengajar kepada pelajar. Pengajar mendominasi muridnya. Ini mengasumsikan bahwa guru mengetahui semua hal, siswa tidak mengetahui sesuatu apapun. Guru bercerita, menentukan dan menerangkan informasi yang harus diterima, dihafalkan, diulang oleh siswa secara mekanis. Transfer informasi ini menjadi lambang dan instrumen penindasan yang melarang dan menghalang-halangi penyelidikan, kreativitas dan dialog.

Penindasan bagi Freire adalah tidak manusiawi apapun alasannya, karena penindasan sesuatu yang menafikan harkat kemanusiaan (dehumanisasi). Dalam bahasa Freire, dehumanisasi berarti keadaan dimana seseorang kurang dari manusia atau tidak lagi manusia (Freire, 2004:18). Yang terjadi sebagai bentuk ungkapan nyata dari proses alienasi dan dominasi karena eksistensi seorang individu menjadi kabur dan hilang disebabkan sempitnya pola pikir sehingga 'bahasa' yang merupakan refleksi dari kemampuan berpikir seseorang untuk merepresentasikan realita yang dialami telah menjadi kebisuan (Freire, 1985: 67).

Dehumanisasi bukan hanya menandai mereka yang tidak sadar bahwa kebebasan dan kemanusiaannya telah dirampas, tidak sadar bahwa mereka bisu dan dibisukan, melainkan (dalam cara yang berlainan) menandai pihak yang telah merampas kemanusiaan itu, dan merupakan pembengkokan cita-cita untuk menjadi manusia utuh sebagai individu yang merdeka, baik dalam proses berpikir serta berperilaku.

\section{Pendidikan Gaya Bank}

Dalam usahanya untuk melanggengkan kebudayaan bisu, pendidikan formal menem-puh dua cara, melalui sistem pendidikan dan relasi dominatif guru terhadap murid. Pertama, Sistem pendidikan termanifestasikan ke dalam kurikulum yang diatur oleh negara. Posisi kurikulum sebagai fenomena, distandarisasi oleh negara untuk semua jenjang pendidikan, Kurikulum 
sebagai sebuah tradisi yang selektif yang menyediakan kebutuhan murid melalui seperangkat pengetahuan untuk memiliki berbagai kebutuhan pragmatis yang akhirnya hanya terjebak pada logika komodifikasi. kurikulum ini mempertegas negara sebagai agen penindasan dalam dunia pendidikan.

Kedua, Model pendidikan formal menjadi anak sebagai obyek dalam proses belajar-mengajar, menjadikan guru sebagai pusat kebenaran. Dalam relasi ini, dominasi guru seringkali merepresi anak dan menjadikannya individu yang pasif karena tidak dilibatkan dalam proses belajar-mengajar. Terang saja hal ini akan menumbuhkan kreativitas siswa dan tunduk dalam payung besar standarisasi sistem pendidikan.

Salah satu instrumen penting dari sistem pendidikan formal adalah ijazah, hal ini menurut Qaryah Thayyibah tidak lagi penting. Hal ini berdasarkan motivasi ijazah yang akan diperuntukkan bagi dunia kerja, negara mengorganisasi warga negaranya untuk menjadi tulang punggung dunia kerja. Ijazah juga bukan tanpa masalah, karena ijazah sejatinya tidak bisa menjadi tolak ukur yang sesuai, karena indikator yang digunakan sama, namun hakekatnya manusia memiliki kemampuan yang berbeda. Maka dari itu, Qaryah Thayyibah mengutamakan hasil karya sebagai sebuah legitimasi atas jerih payah belajar, karena dengan karya lebih kongkret daripada selembar kertas ijazah. Karena karya disesuaikan dengan minat dan kemauan siswa, bukan diinstruksikan dari pemangku kebijakan sekolah.

\section{Pendidikan Kritis}

Freire mengajukan pendidikan pembebasan, atau yang diistilahkannya sebagai “problem-posing education” yang didasarkan pada kesalingsungguhan demokratis antara guru dan murid. Freire mengusulkan suatu partnership antara guru dan murid terdapat interaksi yang saling menguntungkan. Artinya, guru adalah murid dan murid sekaligus guru. Demokratisasi ini dan metode pembelajaran memacu penelitian, kreativitas dan kekritisan yang mendorong munculnya kesadaran dan constant unveiling reality (Freire, 1985: 56).

Dalam pendidikan hadap-masalah, pendidikan ini meyakini hanya melalui komunikasi dapat menemukan hidup yang bermakna. Pikiran guru hanya dapat murni melalui pikiran murid-muridnya. Guru tidak dapat berpikir untuk murid-muridnya, atau tidak dapat memaksakan pikirannya atas mereka. Berpikir murni, yakni berpikir atas dasar keterlibatan dengan realitas, tidak dilakukan jauh di puncak menara gading, tetapi hanya dalam komunikasi. Jika benar bahwa pemikiran hanya bermakna jika keluar dari tindakan nyata terhadap dunia, maka subordinasi murid terhadap guru tidak mungkin membuat makna itu. Oleh karena pandangan pendidikan ini dimulai dengan keyakinan bahwa program pendidikan semacam itu tak dapat dihadirkan tetapi dicari dengan dialog intensif dengan masyarakat, maka hal ini mensyarakatkan pengenalan pendidikan kaum tertindas, di mana keikutsertaan kaum tertindas diutamakan.

Di Sekolah Alternatif Qaryah Thayyibah, anak berpartisipasi aktif dalam pembentukan kurikulum, dilibatkan secara penuh dan diberikan kebebasan dalam menentukan sendiri metode pembelajarannya.Seluruh kegiatan perencanaan dibasiskan pada kepu- 
tusan anak, hal ini akan berdampak pada anak menjadi nyaman dalam belajar, dan menjadi subyek dalam proses pembelajaran. Pusat dari pembelajaran adalah anak itu sendiri, bukan lagi guru seperti pada pendidikan formal. Kemudian karena dibebaskan ini maka anak tidak lagi terjebak pada metode hafalan sebagai akibat tugas anak sebagai deposito pengetahuan yang tidak mampu mengolah pengetahuan, hanya mengkonsumsi pengetahuan. Dengan sistem seperti ini, maka anak akan semakin analitis karena semakin mengenali dunianya.

Selain sistem pendidikan, tawaran yang tidak kalah penting adalah relasi guru dan murid yang tidak lagi instruktif, namun menjadi relasi yang egaliter, relasi dimana guru dan murid adalah subyek-subyek yang belajar. Dalam relasi ini, tidak ada lagi transfer of knowledge, tak jarang malah guru, yang dalam aktivitas sekolah alternatif Qaryah Thayyibah biasa disebut pendamping belajar banyak dari pengalaman dan pengetahun si murid, kebenaran bukan lagi mutlak di tangan guru. Guru harus memberi kesempatan seluas-luasnya bagi siswa untuk belajar dan memfasilitasinya agar siswa dapat mengaktualisasikan dirinya untuk belajar. Gurupun harus mengembangkan pengetahuannya secara meluas dan mendalam agar dapat memfasilitasi siswanya.

\section{KESIMPULAN}

Lahirnya sekolah alternatif Qaryah Thayyibah didasari atas sikap tidak puas atas pendidikan formal yang tidak terjangkau dan kualitas dari penyelenggaraan pendidikan itu sendiri. Sistem pendidikan yang diselenggarakan oleh negara, tidak mampu menjawab berbagai permasalahan, bahkan pendidikan

menjadi bagian dari permasalahan negara. Kondisi pendidikan saat ini yang komersil, menyebabkan pendidikan menjadi komoditas yang mampu diperjualbelikan, selain itu negara memiliki andil besar dalam mengekang keanekeragaman siswa melalui kurikulum, sebuah standarisasi yang dijadikan acuan dan dipenetrasikan ke seluruh lembaga pendidikan formal.

Melalui refleksi panjang, sekolah alternatif Qaryah Thayyibah hadir dan memberikan alternatif model pendidikan. Pusat dari pembelajaran adalah siswa, bukan lagi guru. Dengan mendasarkan kebutuhan belajar pada siswa, maka proses pembelajaran akan lebih efektif dan didasarkan pada permasalahan yang terjadi seharihari. Guru dan murid menjadi subyek-subyek yang sama-sama belajar. Salah satu hal yang progresif dilakukan adalah tidak lagi percaya bahwa ijazah menjadi hal yang sahih dalam melegitimasi hasil belajar seorang siswa, pasalnya ijazah tidak mencerminkan kondisi nyata seorang siswa, karena untuk meraih ijazah, siswa harus menyesuaikan diri dengan indikator yang telah ditentukan, khususnya oleh Negara melalui serangkaian tes atau ujian. Maka, di Qaryah Thayyibah siswa Didorong untuk berorientasi pada karya, karena karya disesuaikan dengan minat dan kemampuan siswa, dan juga karya lebih konkret daripada secarik kertas berisi angka-angka. 


\section{DAFTAR RUJUKAN}

Bahruddin, Ahmad. (2007). Pendidikan Alternatif Qaryah Thayyibah.

Yogyakarta: LKiS

Denzin, Norman. K \& Yoanna S. Lincoln. (2009). Handbook of Qualitative Research. Yogyakarta: Pustaka Pelajar Dharmaningtyas, Edi Subhan, IFahmi Panimbang. (2009). Tirani Kapital Dalam Pendidikan. Jogjakarta: Pustaka Yashiba dan Damar Press.

Freire, Paulo.(1970). Cultural Action For Freedom. Baltimore: Penguin Book. Freire, Paulo. (1985). Pendidikan Kaum Tertindas. Jakarta: LP3ES

Freire, Paulo, dkk. (2004). Menggugat Pendidikan; Fundamentalis, Konservatif, Liberal, Anarki. Terj. Omi Intan Naomi, Yogyakarta: Pustaka Pelajar.

Freire, Paulo. (2007). Politik Pendidikan:

Kebudayaan, Kekuasaan dan Pembebasan. Yogyakarta: Pustaka Pelajar

Hidayat, Rakhmat. (2013). Pedagogi Kritis:

Sejarah, Perkembangan dan Pemikiran. Jakarta: Rajawali Pers

Ozmon \& Craver. (1986). Philosophical Foundations of Educations. Colombus: Merril.

Pazmiño, Robert W. (1988). Foundational Issues in Christian Education: An Introductionin Evangelical Perspective. Grand Rapids: Baker, 1988)

Schipani, Daniel S. (1988). Religious Education Encounters Liberation Theology. Alabama: Religious Education Press.
Subagi, L. (1985).Kritik Atas: Konsientisasi dan Pendidikan.Teropong Paulo Freire dan Ivan Illich”, dalam Martin Sardy (ed.), Pendidikan Manusia. Bandung: Alumni

Sudjana, H. D. (2000). Manajemen Program Pendidikan Untuk Pendidikan Luar Sekolah dan Pengembangan Sumber Daya Manusia. Bandung: Falah Production

Sutrisno, Mudji. (1995). Pendidikan Pemerdekaan. Jakarta: Penerbit Obor.

Topanimasang, Roem, Rahardjo, Toto \& Fakih, Mansour. (2010). Pendidikan Popular: Membangun Kesadaran Kritis. Yogyakarta: Insist Press 